\title{
LVI. On the supposed moraines of ancient glaciers in Scotland
}

\section{William Kemp Esq.}

To cite this article: William Kemp Esq. (1841) LVI. On the supposed moraines of ancient glaciers in Scotland, Philosophical Magazine Series 3, 18:118, 337-343, DOI: 10.1080/14786444108650310

To link to this article: http://dx.doi.org/10.1080/14786444108650310

册 Published online: 01 Jun 2009.

Submit your article to this journal $[\pi$

Џ Article views: 2

Q View related articles $₫$ 
think is inevitable, that the electricity which is excited in the evaporating vessel on the emission of steam, is independent of concomitant evaporation. I should observe, that the electricity which appeared in the boiler after, as well as shortly before, the exhaustion of the water, was uniformly positive.

Under these circumstances, I think there are certainly grounds for supposing that the same cause which excites electricity in the steam-cloud, produces also the contrary electricity of the boiler; but if this be so, I am not aware that there is any known principle upon which the effects can be explained, especially as the electricity of the boiler appears quite independent of the proximity of the jet.

The transmutation which, under certain conditions, takes place in the electrical states of the boiler and steam-clond, is a part of the subject embarrassed with difficulty. What possible change can the steam undergo in the boiler, either by contact with heated metal, or otherwise, which can cause it to evolve, on its subsequent condensation, the opposite electricity to that which it usually liberates?

The effects of pressure appear equally inexplicable. It seems inconceivable to me that steam should acquire by pressure any property which would not be taken away by expansion, and yet we find that the influence of pressure in the boiler, upon the electricity of the jet, is not destroyed by suffering the steam to dilate before it is ejected.

I fear this paper has extended to a somewhat tedious length, and I shall therefore conclude it here by expressing a hope that what has been stated may have the effect of stimulating inquiry into the curious subjects of which I have treated.

Wm. Geo. Anmstrong.

LVI. On the supposed Moraines of Ancient Glaciers in Scotland. By W Ildiam Kemp, Esq., introduced by a Letter from J. E. Bowman, Esq., F.L.S.

[Illustrated by Plate III.]

To the Editors of the Philosophical Magazine and Journai. Gentuemen,

MR. KEMP, of Galashiels, having favoured me with a M copy of a paper lately drawn up by himself, containing new proots of the former existence of glaciers in Scotland, $\mathbb{I}$ thought it desirable that they should be generally known, because I am aware that some of my ablest geological friends are waiting for further evidence (and wisely so) before they adopt

Phil. Mag. S. 3. Vol. 18. No. 118. May 1841. 
the theory of Prof. Agassiz. I therefore wrote to request Mr. Kemp to publish this paper, and illustrate it by diagrams. In his reply he modestly states that he had no design of doing this, "being, as you will at once perceive, no fit person for preparing papers for the press;" but he grants me full permission to do so, if I think it worthy, and has inclosed the accompanying diagrams, respecting which he says, "These very rude and hasty sketches of those gullied tracts called the Meigle Pots, together with the vale above Holilee, are pretty correct, being copied from sketches taken on the spot. But that of the vale of Galashiels is not so faithful, I having only examined it in detail ; that is, the mounds round Gala House are not at all drawn to the truth, I having as yet got no leisure to take a plan, nor can I for many weeks to come."

Mr. Kemp's account of the "Meigle Pots" is highly interesting and important; and being, as far as 1 know, the only instance as yet observed in Britain of this modification of glacier action, it appears to me that I showld have been remiss had I not suggested its publication. To make it more intelligible, I have given in a note an extract from a short but able account of the Creux and Lapiaz of Prof. Agassiz, by the talented editor of the 'Scotsman,' Mr. C. Maclaren. I will only add, that some of the extensive mounds of gravel described in the paper may possibly have been modified, if not originally produced, by the subsequent action of torrents.

Manchester, 10th Feb., 1841.

J. E. Bowman.

On the Moraines of Ancient Glaciers, \&c. By WM. Kemp. Read to the Galashiels Geological Society, Jan. 29th, 1841.

\section{Gentlemen,}

Having had my attention turned to this interesting subject, first by Mr. Bowman's opinion that the terraces in this neighbourhood, which I attributed to the action of water, are in fact the moraines of ancient glaciers, besides having read in the Athenæum and other periodicals of Prof. Agassiz's discovery of similar evidences in different parts of Scotland, \&c., I, among many others, hailed the announcement with great pleasure, as conviction at once flashed upon my mind, that his discovery, by the clear description given of those ancient moraines, would at once apply to thuse beautiful combs or mounds of gravel that have been so frequently noticed in many parts of the country, of which no satisfactory account had hitherto ever been given. How gratifying to the ardent followers of that science, is the discovery of that great man, in pointing to, and 
Lond.3.Edin. Plit. Nag. Vol I7.PL.III.

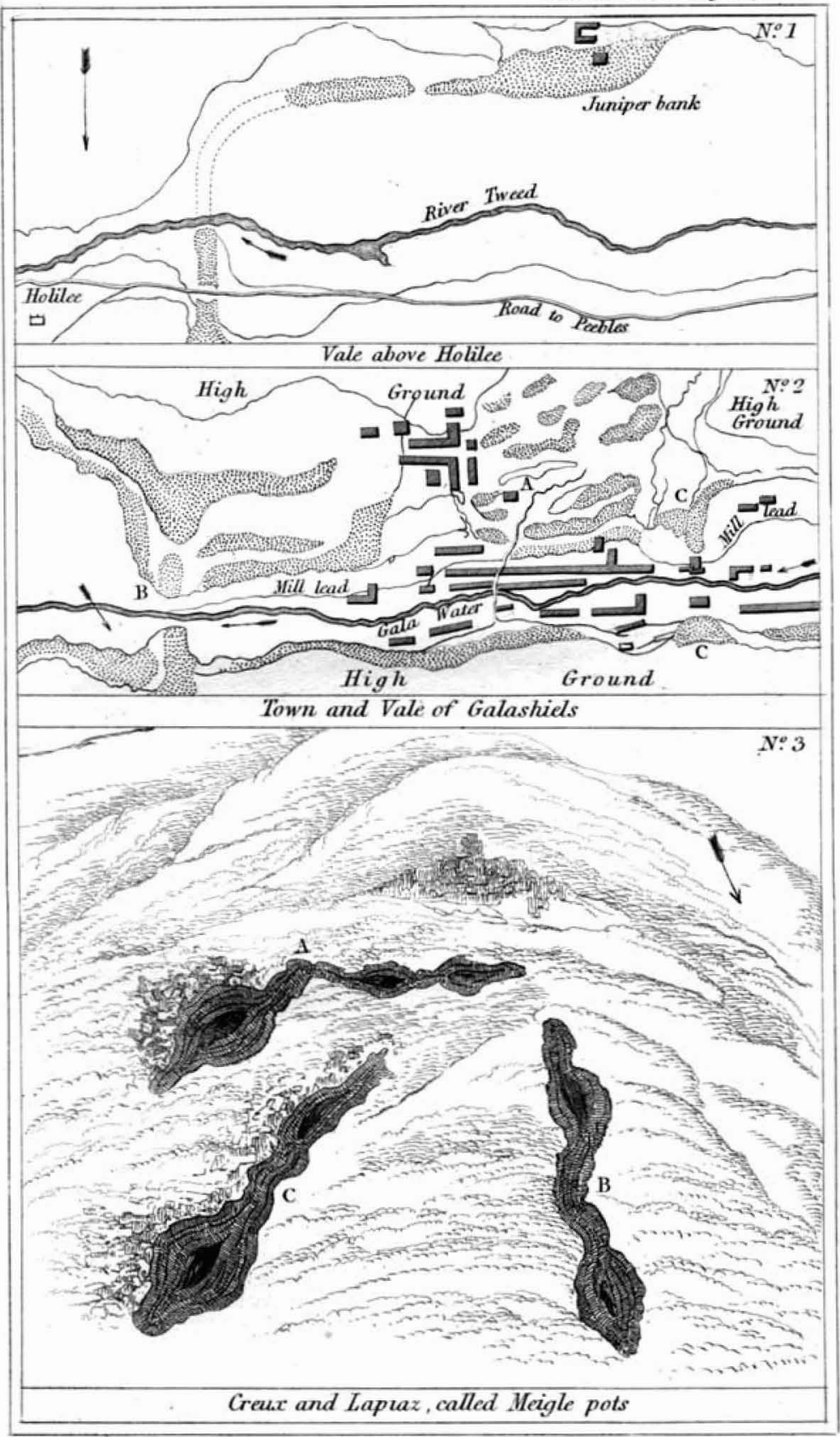


giving such a clear exposition of, these hitherto mysterious formations!

Such moraines as were probably formed by ancient glaciers are very conspicuous in the vale of the Gala, immediately around the town of Galashiels. The vale there will be at one part about three quarters of a mile broad, by upwards of three miles long, surrounded by hills of considerable elevation, except where the Gala enters the vale by a narrow passage at the north-west, and again where it opens to the south-east, and joins the more spacious vale of the Tweed. The glaciers there appear at one time to have extended over the vale to a great height, as lateral mounds of debris can be traced about 300 feet above the level of the water. But I wish to confine my observations to what was possibly a later æra, when the glaciers had much diminished, and were perhaps not above 150 feet high; for it is then that they seem to have left their most legible traces.

Nearly half a mile below Galashiels, where the Gala flows through a narrow channel, with high banks on each side, there is a very conspicuous moraine about 140 feet high upon the north-east side, and about 600 feet long, extending across the lower end of the vale. (See No.2. B.* PI.III.) Upon the southwest side, in a direct line, it can likewise be traced for a considerable distance, where it takes a curvilinear bend to the west, until it becomes imperceptible in the higher ground. The greater part of that moraine is composed of clay and boulders, many of which are quite sharp and angular, but the greater portion are rather well-rounded; and what, perhaps, is worthy of notice, the top, for about 25 feet down, is composed of unstratified gravel and coarse sand, which has seemingly been caused by the water filtrating through the mass while it was being thrown up, and sweeping away the finer comminuted particles. The breach through which the water flows is about 500 feet wide. This is, perhaps, what may be called a terminal moraine, left on its final retreat by the glacier of the Gala valley.

At the west end of Galashiels, rather more than a mile upward from that moraine, the remains of another may be seen, standing out from the banks on each side, the south end in particular being very conspicuous. (See No. 2. C C.) Likewise, along each side of the vale, there are lateral moraines from 50 to 70 feet high, in some places very distinctly marked.

A number of these interesting formations is to be seen near

* The dotted portions indicate the moraines. 
Gala house (see No. 2. A.), in a fine sheltered situation, where the vale extends to the south for a considerable distance, at a lateral opening between the hills.

Nearly parallel with the Gala there is a lateral moraine, which divides the town from Gala house and parks, and behind that there is a series of beautifully formed mounds, ranging nearly parallel one with another. These are not continuous, although some parts are of considerable length : one, called the long knoll, being about 700 feet long, of a serpentine form, averaging 35 feet high; others are like small billocks, from 20 to 40 feet high, with narrow trough-like valleys between. To use a simile, I thought, while examining these interesting relics, that to convey the clearest conception of that place, would be to imagine portions of the rolling waves of a troubled sea to be instantly arrested in their course, while the intervening parts passed onward for a little space, and were then likewise immovably fixed.

Such seems to have been the action of glaciers in the vale of Galashiels, as to have scooped out the basin in some places to an unknown depth, which had afterwards been filled up by impalpable sedimentary sand, over which there is a covering of gravel varying from four to six feet deep, so that a great part of the town may literally be said to be built upon a quicksand*.

There are many lateral moraines along the valley of the Tweed; but the only remarkable terminal ones I have yet observed, are two, one at Dryburgh, the other at Holilee. The first is upon the Dryburgh side of the river, and memorable enough by a fine Doric temple being built upon its surnmit by the late Earl of Buchan. The one at Holilee (see No. 1.) has attracted the notice of many a passing traveller, by its singular uniformity and beauty; so much so, that the most skilful engineer could not construct a finer mound. It crosses the lower end of an extensive vale, immediately below which the hills on each side press close upon the river. The northern part of this mound is about forty feet high, and is composed of rolled gravel. The road to Peebles runs through it. It has swept across and along the opposite side of the vale for about a mile long, but the river has long since carried away a great part of it. A few years ago a splendid portion of it rose out of the vale to the height of sixty feet; but the farmer, unmindful of this fine geological monument of ancient time, after long cursing it for a barren and unpro-

* This sand below the gravel is probably of anterior origin.-J. E. B. 
ductive track, at considerable expense caused it to be much reduced in height, and now the plough (still with difficulty) passes annually over it*.

I have likewise observed several remains of moraines along the vale of the Ettrick. About three quarters of a mile above its junction with the Tweed, at the south end of the fine new bridge upon the road to Selkirk, the approach to the bridge is cut through a very bold one. It sweeps round the lower end of the rich haugh of Lindean, and forward to the side of the water, where it turns obliquely to the stream. About half a mile further up the river at Bridge-heugh, there is another upon the same side of a still bolder character, forming an immense bank about sixty feet high, crossing the vale about two-thirds of its breadth, which is there about half a mile broad, it having evidently once crossed it to the opposite side, as a part in a direct line is still remaining. Following up the water, we observe vast lateral moraines on each side. Upon the north there are three curvilinear ranges of hillocks, some 20,40, and 50 feet high; these join towards the west, in a cross mound, terminating in an abrupt precipitous angular ridge at the side of the water, which at present undermines its broken end. This is fully sixty feet high, and, like the one at Bridge-heugh, seems to have crossed the vale, by the evidence of a remaining portion boldly projecting out of the south bank, a little below the extensive factory of the Messrs. Browns. Gentlemen, these are a few of the leading proofs by which I have attempted to prove the former existence of glaciers along the valleys of this district. You are all more or less familiar with those remarkable mounds I have pointed out; and if you turn to M. Agassiz's description of moraines, you will find that these are similar in every respect.

As a further proof, I have observed the striated and grooved appearance of the rocks in many places in this neighbourhood, particularly at a hill nigh Redhead, by the vale of the Caddon, and even in our own town, at the back of the Buckholmside factory.

At a land-straic or water-shed, between the Gala and the Tweed, about two miles and a half west from Galashiels, on the nurth side, upon a steep spur of the Meigle Hill, which here rises at an angle of near thirty degrees, there are three lines of round hollows with gutter-like tracks between. (See No. 3.) They are known by the name of the "Meigle Pots,"

* This seems to be a beautiful example of a terminal moraine united to a lateral one, very similar to that of the Viesch, described by Agassiz, and represented in the 9th Plate of his Etudes sur les Glaciers de la Suisse. -J. E. B. 
and are each nearly 200 feet long, not in straight lines, but of a serpentine form. The highest (No. 3. A.) is about 200 feet above the vale, running nearly horizontally across the steep spur of the hill, and has three circular hollows in its course, two about fifteen feet deep, and the third about thirtyfive, the tracks between being from 10 to 12 feet deep. The next (No. 3. B.) commences close below the west end of that horizontal one, bending to the right and left down hill, and is more uniform in depth than either of the other two. It contains two deep and finely rounded oval holes, one about thirty, the other forty feet deep. The third (No. 3. C.) begins near the middle of the upper one, and continues down hill in a slanting direction towards the east: it has the most rugged appearance of the three, the rock being bare and precipitous upon the higher side, and terminating at the lower end with a circular cavity about fifty feet deep. The rough markings on the more precipitous or eastern sides of the hollows $a$ and $c$ represent the bare rock partially covered with soil and vegetation; but none such occur on the side of $B$, which runs down hill with the ground nearly level on each side, covered with a fine grassy surface.

The sides of these gullies are very steep, although mostly covered with a fine grassy surface. It is evident they had been originally much deeper, having been greatly filled up by debris, which from time to time has fallen from the heights above*. By what means can we conceive these hollows to have been scooped out of the rock, except by the agency of water, and by water falling from a considerable height? The rock seems favourable for being worn down in that manner, the graywacke strata rising near to the perpendicular, and the beds of the rock being thin, intersected with numerous cutters (joints). Yet where is the Water? None runs there now, nor can ever have run there in the present state of that locality. It seems to me likewise that these hitherto unaccountable ravines have been clearly explained by $\mathbf{M}$. Agassiz in his description of the Creux and Lapiaz, names given to similar holes and guttered tracks which he had observed upon the flanks of the Swiss Alps, and which, he says, have been worn out by water pouring through fissures in the glaciers while they were slowly pressing onward $\uparrow$.

* The Meigle Hill rises about 450 feet above the rude pillar represented in the sketch No. 3. This pillar stands about 60 feet above the upper line of hollows marked $a$, and is built on the lowest terrace $I$ can trace in that quarter, which is No. 10 of the series described in Chambers's Journal; but others are more distinctly marked upwards to the south-west.

+ On the sides of the Swiss valleys, round holes, such as cascades make, 
Gentlemen, however hastily surveyed and imperfectly described, this is still another proof in confirmation of the glacier theory in Scotland, so lately promulgated by the great philosopher of Neufchatel, to whom the geological world is so deeply indebted, by revealing so bright a page in the dark history of the past. W. KEMP.

LVII. An Examination of the Phanomena of Conical Refraction in Biaxal Crystals. By R. PotTer, Esq., B.A.*

THE verification of the two species of conical refraction, which were discovered by Sir William Hamilton to be results of Fresnel's analytical expression for the wave surface in biaxal crystals, forms an epoch in the progress of the conversion of the scientific world to a belief of the undulatory theory of light. Many waverers were confirmed in their belief by so singular a coincidence of theory and experiment; and Professor Lloyd, who made the experiments, had a harvest of reputation from them, such as is seldom reaped in the field of science.

I joined with the scientific world, in the confidence which it gave to Professor Lloyd's investigations; and although I had seen the undulatory theory fail in so many important cases, yet I believed that the true law of refraction in biaxal crystals had been discovered by Fresnel, as certainly as that of uniaxal crystals has been by Huyghens; but in both cases from wrong premises. It was from a desire to view these interesting phænomena, that I availed myself of an opportunity

are sometimes found in the rock, but in places remote from running waters, and where the form of the surface will not permit us to suppose that any cascade could ever have existed. In other cases, a long, sinuous, dry, water-worn gutter or channel is observed, the course of which runs across instead of along the natural declivity of the ground. The study of the glaciers has enabled Agassiz to find a key to these erigmatical phænomena, which had perplexed previous inquirers. Streams of water flow along the surface of a glacier, and when one of these falls into a fissure which is open to the bottom, if it forms a cascade, it cuts a round cavity in the rock with the gravel and sand which it either finds there or carries down with it, as some of our rivulets work out the hollows termed caldrons. If the glacier is travelling downwards the cascade will travel with it, and convert the round cavity into a long gutter; or supposing the water to reach the bottom without falling in a cascade, still, in finding an issue below the glacier, it will be compelled to follow the sinuous openings left by inequalities in the bottom of the ice, and thus take a course at variance with the natural inclination of the surface. We have here an explanation of the Creux or holes, and the long water-worn gutters found in such unlikely situations, which bear the local names of Lapiaz or Karren. These are chiefly observed where the rock is soft, and are seldom visible on the granite,Scotsman.

* Communicated by the Author. 